DOI: $10.1515 /$ hssr -2016-0021

\title{
The Socio-Linguistic Paradox of Goa
}

Luís Filipe F. R. Thomaz*

University of Lisbon, Portugal

\begin{abstract}
This article sets out to explore the socio-linguistic situation of Goa, a small territory corresponding to the former district of Goa of the Portuguese Estado da Índia, occupied and annexed by India in 1961. Goa had to choose between local language, Konkani, and the language of the neighbouring state of Maharashtra, i. e., Marathi, which was traditionally used as a cultural language by the Hindus of Goa, who nowadays form the large majority of the population. Even if virtually every Goan is able to speak Konkani, this was, according to recent statistics, the mother tongue of only $61 \%$ of the population of the state, the rest being forms by people from other parts of India, who migrated here. This phenomenon explains the feeble proportion of Konkani speakers in the total population of the state, which favours the resort to English as a means of communication and explains why Konkani only keeps an elevated status in churches, where it is currently used for praying and preaching. Drawing upon historical facts, but also on socio-linguistic consideration, we will try to explain this paradox.
\end{abstract}

Keywords

Goa, English, Konkani, Christians, Hindu

* Retired professor of the University of Lisbon, New University of Lisbon and Catholic University of Portugal; researcher of the Centre of Studies of Religious History (Catholic University of Portugal) and of the Centre of Overseas History (New University of Lisbon). Universidade Nova de Lisboa, Avenida de Berna, 26-C / 1069-061 Lisbon, Portugal; luisfilipethomaz@yahoo.com 
Goa is a small territory of about $3,700 \mathrm{~km}^{2}$, whose boundaries coincide with those of the former district of Goa of the Portuguese Estado da India, occupied and annexed by India in 1961. Traditionally it was sub-divided into two regions: the Velhas Conquistas ("Old Conquests") formed by the fluvial islands that lie between the mouth of Mandovi River and that of the Zuari, the largest of which is Tissuari Island, conquered by the Portuguese from the sultanate of Bijapur in 1510, to which were added c. 1540 the Terras Firmes (dry-lands) of Bardez and Salcete, granted to the Portuguese by Assad Khân, governor of the region on behalf of the Sultan of Bijapur; and the Novas Conquistas ("New Conquests") annexed by the Portuguese between 1713 and 1788 and twice as large as the Old ones. This distinction is important from the cultural point of view for, as we shall see hereinafter in more detail, the population of the Old Conquests had almost entirely become Christian by the end of the $17^{\text {th }}$ century, whereas that of the new ones remained mainly Hinduํ.

According to the 2011 census, in Goa, in a total population of 1,458,545 people, $66 \%$ were Hindu, 26.5\% were Christian, and $8.3 \%$ Muslim; but these figures need some clarification, as we shall see below. The archdiocese of Goa, which also comprises the former Portuguese territories of Diu, Daman, Dadrá and Nagar Aveli, counts a total population of 1,818,000, out of which 640,616 are Catholics.

After the annexation by India, the people of Goa and of the other former Portuguese territories of Daman and Diu had to choose, in a referendum, between remaining united, as an Union Territory directly ruled by the Central Government, and merging into the neighbouring states: Maharashtra, in the case of Goa, and Gujarat in that of Daman and Diu. It was the first option that won, but afterwards there developed in Goa a strong movement for the transformation of Goa into a state, and in 1987 it was indeed separated from Daman and Diu, which remained a Union Territory, to become an autonomous state, the smallest, but only the fourth less populous of India.

After the independence of India in 1947 the federated states roughly corresponded to the administrative divisions of British India and Nehru; fearing local nationalisms, they tried to hinder any change of boundaries aiming at making states to coincide with linguistic divisions. 
Nevertheless, this tendency finally prevailed, and most of the states of the Union came to correspond to the domain of local languages, as in Europe, since 1848, independent states tended to do. Thus there is in each state a local language officially recognized and used by the administration, besides Hindi and English, which are the official language used at the national level.

In this context Goa had to choose between local language, Konkani, and the language of the neighbouring state of Maharashtra, i. e., Marathi, which was traditionally used as a cultural language by the Hindus of Goa, who nowadays form the large majority of the population. They often argued that Konkani was but a dialect of Marathi - which is not exact - and therefore could not become an official language. This issue brought about a strong contest and even a turmoil in the streets, where barricades were risen, and the Central Government had to intervene, decreeing that the official language of the new state should be Konkani, but written in the Devanagari characters used for Marathi (and not in the Latin characters used by Christians). Nonetheless, the Catholic Church kept printing liturgical books, translations of the Bible, etc., in the Latin script, in accordance with the use introduced by the Jesuits in the $16^{\text {th }}$ century, even if printing in Devanagari characters benefits from subventions of the Government. We may note en passant that technically, both systems are acceptable, though the Romanized one appears to correspond somewhat more accurately to the current pronunciation, as we shall see hereinafter ${ }^{2}$.

In fact Konkani is a Neo-Aric or Aryan language, the southernmost language derived from Sanskrit, if we leave aside Simhalese, the native tongue of Ceylon or Sri Lanka, which is a very particular case, whose origins are not perfectly clear. The name of Konkani comes from Konkan, the traditional name given to the narrow strip of lowlands between the Western Ghats and the Arabian Sea, from Bombay to Goa. The name is ambiguous, because it is also used for the Marathi dialect spoken in Northern Konkan, from Bombay to Savantvâdî, contiguous to North Goa. Goa Konkani is a different language though akin to Marathi, to the same degree as, for instance, Portuguese is different from Spanish. It is spoken not only in Goa and Savantvâdî (a taluka or sub-district of Maharashtra, with some 50,000 inhabitants) but also by significant minorities, along the Canara coast, south of Goa, up to Mangalore; these 
minorities, mainly Christian, are scattered among speakers of Dravidian languages, such as Canarese or Kannada and Tulu. Canara coast is part of Karnataka, where official language is Kannada, whereas Savantvâdî is part of Mahrashtra, whose official language is Marathi. Thus, Konkani is an official language only in Goa.

None the less, it is virtually impossible, when one goes through the territory, to find any public advertising, information or publicity written in Konkani, except perhaps at some churches, all the rest being written in English. Moreover, there is no daily newspaper in Konkani; the only one that existed, Sunaparant, in Devanagari characters, was discontinued about one year ago. However, there are five daily newspapers in Marathi (Gomantak, Navprabha, Tarun Bharat, Goa Doot and Pudhari) and five others in English: the secular $O$ Heraldo, now Herald, formerly in Portuguese but published in English since 1983, The Navbind Times, the Gomantak Times, The Goan, and the Goa edition of The Times of India. Konkani only competes with English in the field of weekly and monthly publications, where four publications (Gulab, Dor Mboinneachi Rotti, the $V$ avraddeancho Ixtt, edited since almost one century ago by the Missionary Society of Our Lady of Pilar, and a recent one, Amcho Awaz) coexist with six in English: Goa Today, Business Goa, Viva Goa, Planet Goa, The Goan Observer and the Renewal, which belongs to the Archdiocese of Goa and was formerly published in Portuguese under the name Renovação.

In fact, there have always been people who cultivated Konkani language, especially for poetry. Among the writers who recently did so we can mention the poet Manohar Sar Dessai, who also wrote in Portuguese, English and French, Prof. Olivinho Gomes, who translated the Portuguese national epics Os Lusiadas (1572) into Konkani, both in Devanagari and Latin characters, and, perhaps chiefly, Mgr. Caetano da Cruz Fernandes and Fr. Manuel Gomes, who translated the whole Bible into Konkani, the Novo Korar (New Testament) having been printed in 1974 and the full text of both Testaments (Povitr Pustok, literally "Holy Book") in $2006^{3}$.

Nevertheless, albeit virtually every Goan is able to speak Konkani, this was, according to recent statistics, the mother tongue of only $61 \%$ of the population of the state, since the rest is formed by people of other parts of India, who after the integration of Goa into the Indian Union 
migrated thither, Goa being the state with the highest rate of income per capita of the whole country (about 2.5 times the national average). This phenomenon, combined with its counterpart, the emigration of Goa Christians, with which we will deal later, explains both the high proportion of Hindus and the feeble proportion of Konkani speakers in the total population of the state, which favours the resort to English as a means of communication.

Anyhow, cultivated Goans seldom use Konkani while talking amongst themselves; they only use it to talk with servants, home-maids and other persons of lower social status. Except among some families who kept its use and still prefer to communicate in Portuguese, the new generations, who were educated in English, normally use the latter not only as a cultural language but also in everyday communication. It goes without saying that the high level of education in Goa favours the spread of English. Thus, Konkani only keeps an elevated status in churches, where it is currently used for praying and preaching.

This paradox can only be explained by history, with the aid of some general concepts of socio-linguistics.

\section{Historical background and geographic context}

First of all, we must note that throughout the centuries Konkani was never used as an official language: under the Kadambas (c. 960-1310), the brightest dynasty that ruled Goa in old days, the court language was Canarese or Kannada, a Dravidian tongue, completely different from Konkani. Under the Moslem rule (1312-1370 and 1469-1510), the official and cultural language was Persian. In the Goa Archaeological Museum there can be seen several stones with inscriptions in Canarese and in Persian. During the period in which Goa was under the rule of the Hindu empire of Vijayanagar (1370-1469), the official language was rather Telugu (the tongue of present day Andhra Pradesh, whence the dynasty came), although the language of the large majority of people around its capital was Canarese.

Apparently, it was because of their subjection to the Canarese Kadambas, and because in the Middle Ages they often wrote in Canarese characters, that until a recent date the inhabitants of Goa were not clearly distinguished from their Kannada neighbours and quite often 
called in Portuguese canarins instead of concanins. In Canara, till quite recently, Konkani continued to be written in Canarese characters, and Fr. Maffei's Konkani-English Dictionary was printed in that script, which is entirely different graphically from Devanagari, though lying on the same principles. Many times, the confusion between Concanim and Canarim has been ascribed to the Portuguese, but it appears that it had already prevailed before the Portuguese conquest of Goa, for the most learned Portuguese writers, such as Tomé Pires in 1515, and João de Barros in 1552, had already noted that such a usage, though current, was not correct. This confusion also existed in Gujarat, wherefore the village near Diu where, in 1535, some Goans settled, received the name of Kanadî Vâdâ, "Canarese Village" 4.

Moreover, there was not a Konkani literary tradition. Some inscriptions in Konkani, dating from the $10^{\text {th }}$ century onwards, have been found in Goa, but virtually no literary work prior to the catechisms, etc., composed by the Jesuits, reached us. This void has been ascribed to the fact that in 1548 the bishop of Goa, Dom Frei João de Albuquerque, had ordered the destruction of all the Hindu texts that could be found, which were suspected of fomenting idolatry. Nevertheless it is far from being sure that they were written in Konkani and not in Sanskrit or Marathi. It is quite significant that when the English Jesuit Thomas Stephen (1549-1619) decided to compose a Christian Purâna (religious epics), narrating the creation of the world, the stories of the Old Testament and the life of Jesus Christ, to replace the Hindu Purânas that contained the tales of Hindu mythology, he preferred to do it in Marathi, which already possessed a literary tradition, instead of Konkani, which apparently lacked it. Fr. Thomas Stephen, known as Tomás Estêvão in Goa where he lived from 1579 till his death in 1619, was the author of the first Konkani grammar and of the first catechism in Konkani; therefore, it was not for lacking of knowledge of the local language that he did not use it for his purpose. On the other hand, when bishop Albuquerque ordered those books to be burnt, only the Old Conquests were under Portuguese rule. If there existed a Hindu literature in Konkani, at least part of it might have been preserved in what is nowadays the New Conquests, which were under the tolerant rule of the Sultans of Bijapur, and where Pondá remained as an important Hindu 
religious centre till our days.

With the Portuguese conquest in 1510, Portuguese replaced Persian as official language of Goa. In the first half of the $16^{\text {th }}$ century there were some endeavours to convert the local population to Christianity, which culminated in 1541 with the creation of a "Brotherhood for the Conversion of Gentiles" and of a seminary to train local clergy. However these endeavours took a systematic character only after the arrival of the first Jesuits, led by Fr. Francis Xavier, in 1543.

The Jesuits played an important role in Goa as well as in the rest of the Portuguese dominions, not only in the field of evangelization but also in that of culture. They had colleges in almost all Portuguese establishments in the East. The main one was St Paul's College in Goa, which in 1563 already had 645 students, coming from every country of Asia, from Persia to Japan. Jesuits had special instructions from their founder, St Ignatius of Loyola, to learn local languages and use them in preaching. They produced an array of grammars and dictionaries of many Asian tongues, including Konkani. In their college of Rachol, in Salcete (Southern Goa), they had the first typography of Asia, with means to print not only in Latin characters but also in oriental scripts, such as Tamil, Ethiopian and Arabic. In the second half of the $16^{\text {th }}$ century the Jesuits began to take an interest in Hinduism, even if only to refute it, and translated some Hindu texts, starting with the $13^{\text {th }}$ song of the Bhagavadgitâ, translated into Portuguese c. $1560{ }^{5}$.

A militant policy of exclusion of Hindus, protection to converts and conversion à outrance had meanwhile been put in practice under the governorship of Dom Constantino de Bragança (1558-61), who endeavoured to introduce in Goa the spirit of the Catholic CounterReformation in its purest form. Mass conversion was thenceforth sought by the civil as well as by the ecclesiastical authorities, often by oblique means, such as compelling every inhabitant of the territory to listen periodically to Christian sermons, demolishing the Hindu temples and forbidding Hindu ceremonies; and, on the other hand, offering several privileges to the converts, such as exemption of certain taxes and priority to be appointed to charges such as those of interpreters of the Portuguese administration. Beside this, there were, especially for women, the advantages of the Portuguese inheritance laws, which unlike 
customary Hindu laws gave them the same rights as men had. Rather tacitly, the authorities tolerated the Hindu system of castes, which indeed lasted till nowadays among the Goa Christians, though spoiled of its religious significance and consequences, such as the concepts of ritual pureness and of untouchable people. This gave the upper castes, namely Brahmins and Chardós, the possibility of keeping, once converted, their social status and their ascendance over other people.

There were two main reasons for such a policy: on the one hand, the Crown wanted to enhance the security and the social stability of the capital of the Portuguese domains in the East, ensuring the fealty of the population to the authorities. In those times religious ties were looked upon as more important than any others, and in Europe, after the troubles caused by the Reformation, the principle cuius regio eius religio had been generally accepted; this meant that it was up to the rulers to choose the religion of each state, which the subjects had to follow. On the other hand evangelization was regarded as a duty of every Christian prince, and, especially since the Counter-Reformation, as a core element of the Portuguese imperial ideology; therefore the Portuguese Crown aimed at establishing in Goa a basis for the evangelization of the East, and this is what explains the enormous concentration of religious orders and regular clergymen, who by the end of the $17^{\text {th }}$ century amounted to some 1,300 people 6 .

Of course, theologians asserted that conversion should be free in order to be valid; and in 1545, an assembly of notables, canonists and other ecclesiastics had almost unanimously rejected a proposal of the King of Tanor, in Kerala, to cleave to Christianity in return for military help. In practice, however, less fair means, such as those mentioned above, were often resorted to in order to obtain mass conversions.

It is, however, important to note that this problem was proper to Goa, the other territories under Portuguese rule having different social and cultural situations and, therefore, their own specificities. It suffices to note that the policy of mass conversion put in practice in Goa was not carried out in the same manner in other territories. Many royal orders, such as the instructions given by the Queen-Regent Dona Catarina de Áustria to Dom Constantino de Bragança in 1558 7, explicitly stipulate that this policy of mass conversion was to be carried out "in Goa Islands", which theoretically appears to exclude de Terras Firmes of 
Bardez and Salcete, respectively North and South of the Islands; but, of course, it would be quite difficult to put in practice a policy on one of the banks of a river and another on the opposite one. So the difference is noteworthy only between Goa and the other Portuguese settlements in India, such as Daman, Diu, etc.

In practice, the captains of the different strongholds enjoyed a large autonomy, which increased with the distance to Goa and with the discontinuity of the communications caused by monsoons. Thus, de facto, the powers of the captains regarding internal as well as external policy were quite large, and each one followed his own policy, within the limits imposed by the local conditions and by the very nature of the settlement. As regards religious policy, the situation was strikingly different in cities where the Portuguese were mere guests of the local rulers and did not exert any jurisdiction outside the walls of their strongholds, as was the case of Quilon, Cochin, Cannanore and Chaul, and in places where they enjoyed full sovereignty, such as Goa, Bassein, Daman, Diu and Malacca. Hormuz is yet another case, since it was ruled by a local Muslim king, under the suzerainty of the Portuguese monarch.

Spontaneous colonies of Portuguese merchants, such as Santhome of Mylapore, Nagapattinam or Macao, even after their official recognition as Portuguese municipalities by the Spanish Kings of Portugal (15801640), who wished to secure their fealty, were yet a different case, since to a certain extent they lived between two dependences, upon Portuguese authorities and upon surrounding powers. In those settlements there were normally no officers paid by the Royal Exchequer, a fact that certainly entailed a larger autonomy. In Mylapore even the religious orders lived upon land revenues granted by the Hindu King of Vijayanagar.

The case of Diu is the clearest: it was a strategic position, between the Arabian Sea and the Gulf of Cambay, which had been, from yore, the economic lung of India, and remained an important trade centre. According to the first budget of Portuguese India, the Tombo da India complied in 1555, the income of Diu custom-house was 43,200,000 reais a year, that is to say, one half of the income of those of Hormuz, Goa, Malacca and Bassein together, which amounted to 86,000,000 reais; it thus represented $22 \%$ of the whole revenue of Portuguese India. As the 
Portuguese Crown lacked capitals to invest in the commerce of East Africa, in 1670, this was granted for a century to a company of Hindu merchants of Diu ${ }^{8}$. The mazanes (mahâ jan, "grand men"), i. e., the notables of the Hindu community, who enjoyed de facto a large freedom of worship, entreated the King to confirm their privileges, which was done by a royal decree in $1705^{9}$.

In fact, places such as Diu, Malacca and Hormuz were mainly intended to be commercial emporia and ports of call for the Portuguese trading network. Foreign merchant communities played a crucial role there, as commercial intermediaries between the Portuguese and their motherlands. In Malacca the economic leadership was in the hands of the so-called Kelings - i. e., "people from Kalinga", a region of East India roughly correspondent to present-day Andhra Pradesh — in fact rather Tamil speaking chettis (traders) from Tamilnadu, further South, who were masters of the spice trade of the Archipelago, bartering spices mainly for Coromandel fabrics ${ }^{10}$. Especially during the first decades of Portuguese presence in Malacca, the Keling merchants often appear as commercial partners of the Portuguese Crown; among others, the first Portuguese ship to reach the Chinese coasts was fitted out in partnership between the King of Portugal and the Tamil merchant of Malacca Naina Chatu.

Logically, it was important to keep good relations with these mercantile colonies, and therefore they were seldom importuned with too persuasive devices to obtain their conversion into Christianity, as those used in Goa. Therefore, whereas in Goa the proportion of Christians reached at least $80 \%$ of the local population, in the other Portuguese settlements of the East Indies, the number of Christians hardly exceeded a few hundreds, out of a population of some thousands, that is to say, never more than $10 \%$.

Leaving aside those settlements and coming back to the particular case of Goa, we must note that in the New Conquests, incorporated during the $18^{\text {th }}$ century, that is to say after the period of militant Counter-Reformation, the adopted policy was entirely different: religious freedom was granted to Hindu and Moslem people, especially under the rule of Sebastião José de Carvalho e Melo, Marquis of Pombal, PrimeMinister of King Joseph I (1750-1777), who promulgated a series of laws giving the Goans the same rights as mother-country Portuguese and the 
Hindus almost the same rights that Christians had. Later on, a code of laws based upon their customs was promulgated. Evangelization took place here as well, but without the same zeal and, therefore, with modest results: the proportion of Christians in the whole population only reached about $20 \%$ in the taluka (district) of Quepém, remaining near 10 $\%$ in the other six talukas, being especially low in Pondá, which has been, throughout the ages, the main Hindu centre of Goa.

All this historical background ought to be borne in mind while trying to understand the specificity of the Old Conquests in the context of the Portuguese empire.

It is also important to note that the contrast between the Old and the New Conquests gradually faded out owing to several phenomena. The most important is that of the emigration of Christians. Christians of Goa have a cosmopolite mentality, quite different from that of their Hindu countrymen, owing especially to the abolitions of the array of taboos which considerably limit the life of the latter out of their own milieu. Sanvordencar, a Hindu writer from Goa, expressed this contrast in a beautiful sentence: "The Hindu turns his home into his world, whilst the Christian turns the world into his home"11.

Excepting, to a certain extent, the popular migration to Bombay from the $19^{\text {th }}$ century onwards, Goan emigration always had the character of an élite migration. The cultural development of the territory was faster than the economic one, which only recently, owing especially to tourism, came to take place. Conversely, owing chiefly to the action of religious orders, the formation of a cultivated local élite quite assimilated to Portuguese culture was quick. Since the 17th century there has been teaching of Medicine and Theology at university level; though a faculty of Law has never been created during the Portuguese period, it was also possible to become a lawyer studying at home and doing the exams before the judges of the Relação or Cassation Court, created in 1545. Nevertheless, in Goa, most upper functions of the administration were given to reinóis (people from the Reino, "the realm", i. e., the mothercountry) and to the so-called descendentes (noblemen of Portuguese origin settled from yore in Goa and around Bassein). This pushed the native élite to migrate into other Portuguese territories, such as Macao, Timor and chiefly Mozambique, where it was easier to find a job. For instance, 
whereas till the end of the Portuguese rule, all the Archbishops of Goa (titled "Patriarchs of the Indies" since 1886) were sent from Portugal, the first bishop to establish residence in Timor, Dom Frei Manuel de Santo António (1697-1722) was from Goa; and so was the first secretarygeneral of the government of Mozambique when the territory became autonomous in 1752. Other Goans reached important positions in the Portuguese motherland, especially in universities, and three Portuguese prime-ministers, including the present-day one, have been of Goan origin. In the $19^{\text {th }}$ century, when the British unified India, many Goans who, on account of their hybrid culture, easily fulfilled the functions of middlemen between them and the native population, entered the civil administration or the army in the territories directly ruled by the British as well as in the feudatory states, and many others migrated to the British colonies in East Africa.

The void created in the Old Conquests by this long-lasting bleeding was fulfilled by the migration of Hindus from the New Conquests and, after the annexation to India in 1961, also from other states of the Indian Union, especially Karnataka, Maharashtra and Kerala; and thus the contrast between both regions tended to gradually fade out. Christians only remained predominant in the rich rice-producing taluka of Salsete, where they still represent c. $70 \%$ of the local population. In the whole territory the number of Hindus has surpassed that of Christians, since 1910. Nowadays it is roughly reckoned, perhaps with some exaggeration, that there are c. 1,000,000 Christian Goans, out of which only c. 390,000 live in Goa, the others living abroad or scattered throughout India, especially in Bombay, where they are c. 100,000. In Pakistan they are c. 30,000, in Portugal between 80,000 and 100,000, and in the Persian Gulf c. 20,000 . In East Africa their number amounted to 40,000 but it has decreased since the independence of the British territories after the second World War.

This double phenomenon, emigration of Christian Goans and immigration of Hindus, does not favour the use of Konkani, since the emigrated population easily loses contact with it, local Hindus traditionally prefer to resort to Marathi as a cultural language, and people from the rest of India hardly know it. 


\section{The late 17th Century Quarrel and Thenceforward}

In 1857 Joaquim Heliodoro da Cunha Rivara, secretary-general of the government of Goa and strenuous defender of the Konkani language, ascribed the subaltern statute it kept till his days to a struggle that took place in Goa by the end of the $17^{\text {th }}$ century; but, though thoroughly recording the events, he appears not to have understood the social and political tensions that lay behind them.

The quarrel broke out when, on 27 July 1684, the viceroy Francisco de Távora, count of Alvor, published an alvará (ordainment) enacting that, "to facilitate the communication between everybody", all the natives of Goa should learn Portuguese within three years, upon which the local language, Konkani, would be banned ${ }^{12}$. This utopian measure which, of course, hardly could have any results - has often been mentioned, but seldom interpreted; it has even been pointed out as a sign of a deliberate glossophagic policy, of which, nonetheless, no other instances are known.

In fact, the question is quite complex. Even though in the Roman Catholic Church the sole language used in official liturgy was Latin, in activities such as catechization, preaching, more or less private devotions, etc., local languages were largely used. In 1541, when a seminary was founded in Goa, an agreement was done between the Portuguese authorities and the gavnkars (full members of village communities) of Goa Island, whereby rents heretofore allotted to the maintenance of Hindu worship should be destined to that of Christian churches and clergy. As per this agreement, in the future, native clergymen would be preferred as chaplains of the small churches that already existed in the island, "so that people of the country feel more content, and easier receive from them the teaching, on account of the language as well as of the nature"13. Two years later, with the arrival of the first Jesuits, evangelization at a large scale began throughout the Indian Ocean. As we have seen, the Jesuits were advised by their superiors to learn the local languages and produced therefore grammars and dictionaries of numerous Asian languages - even of literary languages such as Sanskrit - most of which are still inedited in their general archives of Rome and in several Portuguese libraries. During the $16^{\text {th }}$ and $17^{\text {th }}$ centuries at least four Jesuits compiled vocabularies and grammars of Konkani, while five 
others composed in that language books, such as catechisms, works of Christian spirituality and devotion, etc.

Apparently because of the chronic rivalry between orders, the territory of Goa had been shared among them, so that there was only one order in each district: the Islands of Goa had been assigned to the Dominicans, the dry-land of Bardez to the Franciscans, and that of Salsete to the Jesuits. In spite of a canon of the Council of Trent, promulgated in 1563, that forbade friars and other regular clergymen to become parish priests, most of the parishes of Goa continued to be entrusted to the regulars, as it remains evident from the very lay-out of the churches, which mostly have an annex to be used as the residence of a small community.

It is of paramount importance to note that from the $11^{\text {th }}$ century onwards, and especially since the beginning of the $13^{\text {th }}$, in the Roman Catholic Church, most of the religious orders enjoyed exemption of episcopal jurisdiction, depending directly on Rome, through their Generals, who normally dwelt there or thereabout. In $17^{\text {th }}$ century Goa the regular clergy, who counted up to some 1,730 persons, had become quite rich and influential. Their attachment to parishes is easily understandable, if one bears in mind that it not only allowed to exert a strong influence on the ewes of the parish herd, but also entitled them to collect their tithes.

It is also important to note that most of the religious orders, especially the Jesuits, accepted local people in their ranks only quite late. This exclusion did not lie on grounds of race, a concept that did not clearly exist as yet, but rather on a prejudice against tropical climates, which were supposed to produce indolence and lack of zeal. Because of this Jesuits accepted novices born in cold climates, such as Japanese, Persian converts, etc., but not Creoles, of European origin but born in the tropics, including the Portuguese descendentes of Goa. Because of this, in the $17^{\text {th }}$ century in Goa, the regular clergy was still almost entirely reinol, whilst the secular clergy was already mostly local. The situation only began to change in the next century, when some new local orders were created, whilst the old ones gradually opened their ranks to natives.

The bishopric of Goa had been created in 1534, and raised to the rank of archbishopric in 1558; but owing to the canonical situation described above, the prelates only had an effective authority on the secular clergy, 
who was mainly native. In fact, most of the parish churches continued being entrusted to the regulars, so partly evading the episcopal authority. In 1677 the archbishop Dom Frei António Brandão (1675-78), in accordance with the decrees of Trent, forbade the regular superiors to appoint parish priests, only leaving them the right of presentation, $i$. e., of proposing candidates for episcopal nomination. As the Jesuits of Salsete resisted, he entrusted all parishes to native secular priests. Nonetheless, four years later, under his successor, Dom Manuel de Sousa de Meneses (1681-84), an agreement was reached and the regulars were reinstalled in their parishes.

The first Provincial Council of Goa, held in 1567, the second in 1575 and the third in 1585, had insisted on the need to use local languages in catechesis, preaching and confession; in addition, the latter recommended the ordination of native priests of castes deemed "honourable and clean", so that they could be respected by other Christians, provided they enjoyed a good moral reputation and knew the local language well, besides Latin. In 1592 the fourth Provincial Council went further, decreeing that in all the parishes where the majority of faithful were local Christians, only native priests should be appointed vicars. Finally, in 1606, the fifth Provincial Council gave six months to every parish priest, either secular or regular, to learn the local language, under pain of suspension.

This measure enhanced the supremacy of the native clergy as well as the effective power of the Archbishop. No wonder that it met with opposition, nay obstruction, on the part of religious orders, chiefly the Franciscans. In fact, profiting by the death of Archbishop Meneses, in January 1684, which left the administration of the diocese into the hands of the chapter, the Franciscans of Bardez extorted from the viceroy the alvara of 1684 mentioned above, forbidding the use of local language and rendering compulsory the use of Portuguese.

This was a victory for Franciscans, but a defeat for the archbishopric and the native clergy. As could be expected, when a new prelate was appointed, he reacted violently, publishing a pastoral whereby he forbade the teaching of Portuguese in the schools that existed attached to every parish church, and even the use of Portuguese language by Brahmins and other natives - a measure as radical and utopian as the viceroy's decree, 
and therefore equally devoid of applicability.

Meanwhile, in Lisbon, Franciscans had managed to obtain, in 1687 and again in 1732, the confirmation of the alvara of 1684, and insisted on its fulfilment; but the new Viceroy, count of Sandomil (1732-41), preferred to take an elusive decision, declaring that between the alvará of his predecessor, now confirmed by the King, and the pastoral of the Archbishop, there was no contradiction, since the former applied to persons that had means to send their children to schools, whereas the latter was intended to poor people, who lacked wherewithal to do so.

The story, on whose details we cannot dwell here, comprised many other episodes, including scenes of pugilism between regular and secular priests inside the churches and a mutiny of the Franciscans of Bardez, that led the Viceroy to besiege their convent with troops, artillery and even naval means. Finally, the Jesuits, who had begun to be replaced by secular priests in the parishes of Salsete in 1706, were expelled from the Portuguese domains by the Marquis of Pombal in 1760. In Bardez, the substitution of Franciscans was accomplished between 1729 and 1767, that is to say, half a century before the dissolution of all the religious orders in Portugal by King Peter IV in 1834.

Nevertheless, in spite of the disappearance of regular clergy, which was a victory for the secular one, wholly native, in parish schools Portuguese continued to be taught, and nothing was done to replace it by Konkani.

When in 1843-44, the secondary education, ruined by the expulsion of the Jesuits in 1760, was reorganized in Goa, chairs of Tamil and Hindustani were created in the seminary, and of Marathi and Canarese in the Lyceum or high-school - but none of Konkani, considered a nonliterary language, only apt for the everyday life.

In 1870 the Portuguese Exército da Índia, deemed useless after the general pacification of India by the British, was dissolved, and most of the descendentes or petty noblemen of Portuguese ascent who formed its cadres migrated into other Portuguese territories, chiefly Mozambique and Angola. The community was reduced from about 9,000 to 3,000 souls. This favoured the ascension of the local élite, formed by Christian Brahmins and Chardós who took possession of virtually every post of the administration. Meanwhile the kinship between Indian and European 
languages had been ascertained and the interest towards Indian studies began to increase, in India as well as in Europe. This brought about a change of attitude among Goan Christians who, in the preceding centuries, had showed themselves rather proud of their Portuguese culture, but now began to boast their Indian roots and the ancientness of Indian Civilization. In was then that Christian women began to use sarees on great occasions, such as baptisms, weddings and other social feasts. This movement, which is related to Romanticism in Europe and to Indianism in Brazil, received in Goa the name of Nativism.

In this context, there arose a certain tendency to rehabilitate Konkani, to rewrite its grammar on the basis of Sanskrit grammar, normally in a rather incorrect manner ${ }^{14}$, and even to eliminate Portuguese loanwords, replacing them with vocables borrowed from Sanskrit, exactly as Hungarians were doing in he same period and Turks would do somewhat later, under Kemal Atatürk.

The main efforts to strengthen Konkani were made by a Portuguese metropolitan, Cunha Rivara, whom we already met, and by a Goan, Mgr Sebastião Rodolpho Dalgado, professor of Sanskrit and Konkani in the Faculty of Arts of Lisbon, who published two very comprehensive dictionaries, a Konkani - Portuguese one and a Portuguese - Konkani one, about which we shall talk again in the next section of this article. It is not exaggerated to say that it was with the Konkani - Portuguese Dictionary of Mgr Dalgado that nativism reached its hey-day. Nevertheless, partly because the author went too far, almost inventing a new language incomprehensive to common people, this movement had virtually no consequences: though Goan literature experienced a noteworthy development in that period, everybody kept writing in Portuguese or, especially among the Goan community of Bombay, in English.

Albeit under the authoritarian Salazar regime Goa only enjoyed poor autonomy, on the eve of the Indian annexation solely two important positions, that of Governor-General and that of Archbishop-Patriarch, were always into the hands of the Portuguese metropolitan, all the other functions, including that of President of the Relação, whose jurisdiction reached to Macao and Timor, being more often than not fulfilled by Goans. Nevertheless, very little, if anything, was done to improve the use 
and, chiefly, the social status of Konkani, which was never introduced in schools.

It seems, therefore, that the language contest of the $17^{\text {th }}$ century was not the main cause of the relative stagnation of Konkani, although it may have contributed to maintain the status quo ante.

Anyhow, from the historian's point of view, that struggle is indeed quite noteworthy, as an example of the interdependence of political, religious, cultural and even economic history, and as a sign of the complexity of the Goan society.

\section{An essay of interpretation}

Two consequences arose from this situation: first, in the absence of a literary language generally recognized as a pattern, there was never a linguistic normalization, and Konkani continues to present many variants, according to the regions, the religion and even the caste of speakers; secondly, it seems that at least till the $19^{\text {th }}$ century, it lacked an acrolect, which limited its use to the needs of everyday life.

We must explain, parenthetically, what we mean by this term ${ }^{15}$. In 1965, while studying creole dialects, William Stewart ${ }^{16}$ introduced the notions of acrolect and basilect to describe the coexistence within most languages of two different levels, normally used by the same speakers in different situations. This dichotomy seemed insufficient, and some five years later Derek Bickerton ${ }^{17}$ introduced a third notion, that of mesolect - an intermediate between the other two. In his terminology, which we adopt here, basilect is the basic level of communication, which normally does not require more than 500 different vocables. By mesolect we mean the middle register of communication in everyday life, which requires a vocabulary of about 2,000 words, and syntactical resources that are more developed than those of the basilect. In principle, every language possesses these two registers. Finally the acrolect, which allows one to express all the subtleties required by the juridical, scientific, philosophic and theological thought, needs a larger vocabulary, of at least 20,000 words, though some more endowed languages, such as Sanskrit, may possess a stock of about 150,000 different terms.

It is important to note that, even among highly civilized peoples, many tongues lacked an acrolect, since its function was fulfilled, for 
instance, by a classic language, such as Sanskrit in India, Latin in Medieval Western Europe, Slavonic in East Europe, Arabic in the Moslem World, etc., or by a neighbouring tongue reputed as richer and superior, as was the case of Persian in Moslem India.

As many other vernacular tongues, owing to the use of classic or foreign languages for literary, juridical, philosophic and scientific purposes, Konkani lacked an acrolect. We can assume that, if the endeavour of the $16^{\text {th }}$ century Jesuits to adopt it as Church language were prosecuted, Konkani would develop an acrolect, using its own resources or resorting to the adaptation of Sanskrit terms, borrowing Marathi or even Portuguese loan-words, etc.; but the preference of Portuguese as official and cultural language hindered such a development. It was certainly from that situation that the Konkani - Marathi controversy arose, whereto we have already alluded ${ }^{18}$. From the strictly linguistic point of view, a dialect is a subordinate variety of a language, with its own features, which, in principle, are not sufficient to hinder intercommunication; in that sense, Konkani is fully a language, well distinct from Marathi. Nonetheless, in current speech, the word dialect is often used in a rather cultural sense, to mean a language devoid of an acrolect, and therefore only employed for everyday needs and popular forms of literature, such as songs, tales, etc. It is only in this loose sense that Konkani could be regarded as a mere dialect; hence the controversy.

Undoubtedly, the work of Mgr Dalgado represents an attempt to endow Konkani with an acrolet. Unfortunately, his Diccionario KomkaniPortuguez, published in Bombay in $1893^{19}$, both in Devanagari and Latin script, but following the order of the Devanagari alphabet, is quite comprehensive but hard to use, because of its system of transliteration, which strikingly departs from the usual one, employed since the days of Thomas Stephen ${ }^{20}$. Moreover, given his strong tendency to sanskriticize Konkani, we even wonder whether it really corresponds to an ever spoken language, or rather to the compromise between Konkani and Sanskrit the author thought that people should speak...

In fact, he writes, for instance, phala the word that means "fruit" and is normally pronounced and written foll, nârala the word for "coconut", normally pronounced nal, tiraphala the vulgar name of a kind of pepper which is the fruit of Zanthoxylum rhetsa, DC, currently called, according to 
the regions, tellfoll or tefoll, etc. Sometimes it becomes virtually impossible to find a given word, as we cannot guess under which form it appears in the dictionary. His Diccionario Portuguez - Konkani, published in Lisbon twelve years later in the Latin script ${ }^{21}$, is less ideological and far more realistic, but its influence appears to have been scarce.

Nonetheless, albeit only at the level of a mesolect, Konkani continued developing, chiefly as a Christian language, in Goa as well as in Canara, up to Mangalore and to the confines of Kerala. It was already enriched with numerous religious texts, such as songs, prayers, etc., when in 1965 the Roman Church authorized the celebration of liturgy in vernacular tongues, whereupon the liturgical texts as well as the Bible were translated into Konkani, as we have already noted. Romanized Konkani became thus an important element of the Goan identity, and this explains the present-day strong movement aiming at obtaining from the central and local governments the same statute and privileges that Konkani in Devanagari characters enjoys.

As we have seen, Goans became, like Armenians and Jews, a people mainly living in diaspora; but unlike them, who always cultivate their language as an acrolet used for religious purposes, they rather resort to Portuguese and chiefly to English to fulfil such functions. Thus, though in Portugal and in the former Portuguese domains Goans easily merge into the local society, in non-Catholic territories they keep mainly linked by religious ties, language playing a dim role in their identity out of India.

It is inside India that Konkani, especially Romanized Konkani, in spite of its restricted employ in practice, is a core element of the Goan identity. We can so understand its use by Christian Goans, who no longer form either the majority of the local population or the ruling class of the territory, as a kind of flag.

\section{References}

Antunes, L. F. D. (2001). A presença dos baneanes de Diu em Moçambique (de finais do século XVII ao $3^{\circ}$ quartel do século XVIII). thesis presented to the Universidade Nova de Lisbon.

Bickerton, D. (1975). Dynamics of a Creole System. London: Cambridge University Press. 
da Costa, A. M. (1997). Dicionário de Literatura Goesa. 3 vols. Macao \& Lisbon: Instituto Cultural de Macau \& Fundação Oriente. s. v. "Sanvordencar, Balcrisna Vamona Sinai".

Dalgado, S. R. (Mgr.) (1893). Diccionario Komkanî-Portuguez, philologico-etymologico, composto no alphabeto Devanâgarî com a translitteração segundo o systema Jonesiano. Bombay [repr. New Delhi: Asian Educational Services, 1983].

Dalgado, S. R. (Mgr.) (1905). Diccionario Portuguez - Konkani. Lisbon [repr. New Delhi : Asian Educational Services.1986].

Hambye, E. R. (1986). art. "Goa" in Dictionnaire d'Histoire et de Géographie Ecclésiastiques. vol. XXI. Paris : Letouzey \& Ané, Paris. s. v.

Pereira, J. (1971). Konkani - A Language: a History of the Konkani - Marathi Controversy, Dharwar: Karnatak University.

Ribeiro. O. (1959). "Originalidade de Goa". III Colóquio Internacional de Estudos Luso-Brasileiros - Actas. vol. I. Lisbon, reproced in Aspectos e Problemas da Expansão Portuguesa. Centro de Estudos Políticos e Sociais. Junta de Investigações do Ultramar. Lisbon, 1962. 183.

Rivara, J. H da C. (1876). Archivo Portuguez Oriental. Nova Goa. Imprensa Nacional. 10 volumes [repr. New Delhi \& Madras. Asian Educational Services, 1992], fasc. 6. Supplement. doc. 54. 178-180.

Rivara, J. H da C. (1857). "Ensaio Historico da Lingua Concani". Grammatica da Lingua Concani, composta pelo Padre Thomaz. Estevão e accrescentada por outros Padres da Compania de Jesus. segunda impressão correcta e annotada (...). Nova Goa: Imprensa Nacional

Stewart, W. A. (1964). "Urban Negro speech: sociolinguistic factors affecting English teaching". R. W. Shuy, A. L. Davis \& R. F. Hogan (ed.). (1964). Social Dialects and Language Learning. Proccedings of the Bloomington, Indiana, Conference. Illinois: Champaign. s/d.

Thomaz, L. F. F. R. (1985). "The Indian Merchant Communities in Malacca under the Portuguese rule". Indo-Portuguese History: Old Issues, new Questions, ed. T. R. de Souza. New Delhi :Concept Publishing Cy. 1985. 56 -72.

Thomaz, L. F. F. R. (1999). Early Portuguese Malacca. Macao: Comissão Territorial dos Descobrimentos / Instituto Politécnico de Macau.

Thomaz, L. F. F. R. (2001). "Os antigos gramáticos portugueses e a declinação neo-árica" in Anais de História de Além-Mar. vol. II. 7-32.

Thomaz, L. F. F. R. (2015). "De l'autre côté du monde: Langues véhiculaires et communication interethnique dans l'océan Indien à l'époque de la découverte portugaise ", in J. C. Estenssoro \& C. Itier (coord.). Langues indiennes et empire dans l'Amérique du Sud coloniale / Lenguas indigenas e imperio en la América del Sur colonial [Mélanges de la Casa de Velázquez: nouvelle série. 
tome 45-1 (2015)]. 113-131.

Wicki. J. S. I. (1948-88). Documenta Indica. 17 vols. Rome. vol. IV. doc. 104. pp. 786 \& ss.

${ }^{1}$ As an introduction to Goa History and Society, vide our article "Goa - Une société luso-indienne" in Bulletin des Études Portugaises et Brésiliennes. tomo 42-43. Paris. 1983. 15-44; English version: "Goa: A Luso-Indian Society". Portugal Newsletter. vol. 4. no 9. New Delhi. July 1997. 2-43; Portuguese version in De Ceuta a Timor. Carnaxide: Ed. Difel. 1995.

${ }^{2} V$ ide infra note 18.

${ }^{3}$ I am thankful to my dear friend Óscar de Noronha, from Goa, who imparted me details on this matter.

${ }^{4}$ For further details and references vide our note "Canarim Vará (Povoação de Canarins)" in Diogo do Couto, Década Quarta da Ásia. vol. II. edição crítica anotada e coordenada por M. A. L. Cruz (1999). Notas históricas e filológicas, glossário e índice de antropónimos e topónimos. Comissão Nacional para as Comemorações dos Descobrimentos Portugueses. Fundação Oriente. Lisbon: Imprensa Nacional - Casa da Moeda, 1999, note 113. 110-111.

5 Letter of Fr Luís Frois to his brethren in Portugal, Goa, 8.XII.1560, published by Joseph Wicki. S. I. (1948-88). Documenta Indica. 17 vols. Rome. vol. IV. doc. 104. pp. 786 \& ss.

${ }^{6}$ For further details and references, vide our article "Descobrimentos e Evangelização - Da cruzada à missão pacífica". Congresso Internacional de História 'Missionação Portuguesa e Encontro de Culturas' - Actas. Vol. I. Universidade Católica Portuguesa - Comissão Nacional para as Comemorações dos Descobrimentos Portugueses - Fundação Evangelização e Culturas, Braga, 1993. 81-129.

7 The manuscript of these instructions has recently been discovered in the library of the Faculty of Law of the Lisbon University by Dr. Pedro Pinto; in this moment we are preparing together its publication with an introduction and abundant notes.

${ }^{8}$ Luís Frederico Dias Antunes, A presença dos baneanes de Diu em Moçambique (de finais do século XVII ao $3^{\circ}$ quartel do século XVIII), thesis presented to the Universidade Nova de Lisboa in 2001.

${ }^{9}$ Carta Régia of 12.IX.1705, pub. by J. H. da Cunha Rivara, in Archivo Portuguez. Oriental, Nova Goa, Imprensa Nacional. 1876. 10 tomes [repr. New Delhi \& Madras: Asian Educational Services, 1992], fasc. 6. supplement. doc. 54. 178-180. 
${ }^{10}$ For further details and references, vide our article "The Indian Merchant Communities in Malacca under the Portuguese rule". Indo-Portuguese History: Old Issues, new Questions, ed. por T. R. de Souza. New Delhi :Concept Publishing Cy. 1985. 56 -72. and our book Early Portuguese Malacca. Macao: Comissão Territorial dos Descobrimentos / Instituto Politécnico de Macau, 1999.

${ }^{11}$ Quoted by O. Ribeiro. (1959). “Originalidade de Goa”. III Colóquio

Internacional de Estudos Luso-Brasileiros - Actas. vol. I. Lisbon, reproced in Aspectos e Problemas da Expansão Portuguesa. Centro de Estudos Políticos e Sociais. Junta de Investigações do Ultramar. Lisbon, 1962. 183; about Sanvordencar vide Aleixo Manuel da Costa. (1997). Dicionário de Literatura Goesa. 3 vols. Macao \& Lisbon: Instituto Cultural de Macau \& Fundação Oriente. s. v. "Sanvordencar, Balcrisna Vamona Sinai".

${ }^{12}$ For further details and references on this quarrel vide Joaquim Heliodoro da Cunha Rivara (1857). "Ensaio Historico da Lingua Concani". Grammatica da Lingua Concani, composta pelo Padre Thomaz Estevão e accrescentada por outros Padres da Compania de Jesus, segunda impressão correcta e annotada (...), Imprensa Nacional. Nova Goa; E. R. Hambye. (1986). art. "Goa" in Dictionnaire d'Histoire et de Géographie Ecclésiastiques. vol. XXI. Paris : Letouzey \& Ané. s. v.

${ }^{13}$ Pub. in [Joaquim Heliodoro da Cunha Rivara]. Archivo Portuguez Oriental. Nova Goa. Imprensa Nacional. 1876. 10 tomes [repr. New Delhi \& Madras, Asian Educational Services, 1992] tome V. 161-173.

14 For further technical details vide our study "Os antigos gramáticos portugueses e a declinação neo-árica" in Anais de História de Além-Mar. vol. II. 2001. 7-32.

${ }^{15}$ For further details and references vide our article "De l'autre côté du monde: Langues véhiculaires et communication interethnique dans l'océan Indien à l'époque de la découverte portugaise », in J. C. Estenssoro \& C. Itier (coord.). Langues indiennes et empire dans l'Amérique du Sud coloniale / Lenguas indígenas e imperio en la América del Sur colonial [Mélanges de la Casa de Velárquez: nouvelle série. tome 45-1 (2015)]. 113-131.

${ }^{16}$ William A. Stewart (1964). "Urban Negro speech: sociolinguistic factors affecting English teaching”. R. W. Shuy, A. L. Davis \& R. F. Hogan (ed.). (1964). Social Dialects and Language Learning. Proccedings of the Bloomington, Indiana, Conference. Illinois: Champaign. s/d.

${ }^{17}$ D. Bickerton. (1975). Dynamics of a Creole System. London: Cambridge University Press.

${ }^{18}$ Cf. Dr. J. Pereira. (1971). Konkani - A Language: a History of the Konkani Marathi Controversy. Dharwar: Karnatak University.

${ }_{19}$ Mgr Sebastião Rodolpho Dalgado, Diccionario Komkanî-Portuguez, philologico- 
etymologico, composto no alphabeto Devanâgarî com a translitteração segundo o systema Jonesiano, Bombay, 1893 [repr. Asian Educational Services, New Delhi, 1983].

${ }^{20}$ In the Romanized script retroflex consonants (pronounced with the tip of the tong touching the palate) are noted by double letters $(t t, d d, n n, l l)$, whilst in the Jonesian system adopted by Dalgado in his first dictionary they are represented by under-dotted characters. In the Romanized system the name of the language is written Konknni. The Devanagari and Jonesian systems keep the etymological distinction between long and short vowels, which is no more observed in practice, and noting vowels that have become mute; also etymologically, they note by a short $a$ the sound normally pronounced as an opened $o$, that Thomas Stephen, undoubtedly according with the pronunciation of his time, still noted with an $a$.

${ }^{21}$ Mgr Sebastião Rodolpho Dalgado, Diccionario Portuguez. - Konkani, Lisbon, 1905 [repr. Asian Educational Services, New Delhi, 1986].

\section{Biographical note}

Luís Filipe F. R. Thomaz is a former professor at the diocesan seminar in Dare (Timor), at the University of Lisbon, at the New University of Lisbon and at the Portuguese Catholic University; Researcher at the Centre for Religious History Studies (the Portuguese Catholic University) and the Centre for Overseas History Studies (the New University of Lisbon). Among his books: Nanban Jin: Os Portugueses no Japao (The Portuguese in Japan), CTT Correios, 1993; De Ceuta a Timor (Memoria e Sociedade), Difel, 1994. 